\title{
Antifungal Properties of Protein Extracts from Thai Medicinal Plants to Opportunistic Fungal Pathogens
}

\author{
Juthatip JEENKEAWPIEAM ${ }^{1}$, Supachai YODKEEREE ${ }^{2}$, \\ Sittiruk ROYTRAKUL ${ }^{3}$ and Monsicha PONGPOM ${ }^{1, *}$ \\ ${ }^{I}$ Department of Microbiology, Faculty of Medicine, Chiang Mai University, Chiang Mai, 50200, Thailand \\ ${ }^{2}$ Department of Biochemistry, Faculty of Medicine, Chiang Mai University, Chiang Mai, 50200, Thailand \\ ${ }^{3}$ Proteomic Research Laboratory, Genome Institute, National Center for Genetic Engineering and \\ Biotechnology, Pathum Thani, 12120, Thailand
}

(“Corresponding author’s e-mail: monsicha.p@cmu.ac.th)

Received: 17 October 2019, Revised: 1 May 2020, Accepted: 1 June 2020

\begin{abstract}
Antifungal proteins or peptides (AFPs) are the natural products produced by several life forms including plants as the first-line defenses to infections. The AFPs from Thai plants can be used as new therapeutic agents in the world with growing resistance to conventional antifungals. This study determined the antifungal activities of protein extracts from Thai medicinal plants against important human opportunistic fungi, Candida albicans, Cryptococcus neoformans, Aspergillus fumigatus, and Talaromyces marneffei. Total crude protein supernatants and their precipitated proteins from 10 Thai medicinal plants with the historical usage for treatment of fungal infection were prepared. Most of the protein extracts showed antifungal activities to the tested fungi. The most effective reactivity found in the extracts from Rhinacanthus nasutus, Andrographis paniculata, and Psidium guajava by showing highest activity to T. marneffei ATCC200051 (yeast phase), followed by C. neoformans ATCC90112, C. albicans ATCC90028, T. marneffei ATCC200051 (mold phase), and A. fumigatus NCPF7367. The precipitated proteins from $R$. nasutus and A. paniculata containing antifungal properties were selected for partial purification by size cut-off membrane centrifugation and tested for antifungal activities. A colorimetric broth microdilution method was used to determine the minimal inhibitory concentration (MIC) and minimal fungicidal concentration (MFC) to anti-T. marneffei. The partially purified fractions from $A$. paniculata, and $R$. nasutus showed anti-T. marneffei activity with the MIC and MFC values ranged from 2 to $128 \mu \mathrm{g} / \mathrm{mL}$ and 16 to $>128 \mu \mathrm{g} / \mathrm{mL}$, respectively. Therefore, A. paniculata and R. nasutus can be further subjected to the study of the therapeutic antifungals.
\end{abstract}

Keywords: Antifungal activity, Antifungal proteins, Medicinal plants, Opportunistic fungi

\section{Introduction}

There is a need for alternative antifungal agents since an increase in drug-resistant fungal infections poses a challenge to conventional antifungal therapy. Moreover, infections by opportunistic fungal pathogens remain understudied and underdiagnosed as compared to other infectious diseases [1]. Conventional treatment can be hampered by toxicity, poor tolerability, or a narrow activity spectrum of antifungal drugs [2]. Polyenes, azoles, flucytosine, and echinocandins represent the most common classes of antifungals currently used in the clinics. These agents demonstrated high levels of antifungal activity; however, resistance is reported for all classes [2,3]. Additionally, the repertoire of antifungal agents is rather limited. Treatment of life-threatening invasive fungal infections is still mainly based on drugs discovered several decades ago [4]. 
http://wjst.wu.ac.th

Drugs derived from natural sources play a significant role in the prevention and treatment of human diseases. Nature has strategically placed antimicrobial peptides as $1^{\text {st }}$ line of defense between the host organism and its surrounding environment because these peptides can quickly inhibit a wide spectrum of infectious microbes without significant toxicity to the host organism [5]. Currently, new drugs have been developed based on natural products and they have been very successful especially in the areas of infectious disease and cancer [6]. Fungi and plants have been widely investigated as a source of bioactive compounds including crude extracts, pure extracts, and antifungal protein/peptide (AFPs).

Antifungal proteins/peptides (AFPs) are the naturally occurring products produced by several life forms such as fungi, plants, and insects. They are currently subjected to the development of new antifungal agents [7]. AFP has been demonstrated to have neither cytotoxic nor immunogenic effects on different types of mammalian cells, which is indicative of its excellent potential for medical applications [5,7-9]. Some Thai herbs have been used for the treatment of fungal diseases for a long time without scientific information on whether the antifungal peptides are present. The goal of the study is to determine the AFPs in Thai medicinal plants against some important human fungal pathogens, specifically on Talaromyces marneffei, an opportunistic pathogen that is endemic in Southeast Asia. The knowledge obtained from this study can be continued in the future to identify and characterize the novel AFPs and their potential therapeutic usage.

\section{Materials and methods}

\section{Plant materials and preparation of protein extracts}

Thai medicinal plant taxa were collected from the Herb for Health Unit, Faculty of Pharmacy, Chiang Mai University. Thirty-gram leaves of Senna alata (L.) Roxb. (Ringworm bush or common name in Thai, Chum-Het-Thet), Piper betle (Betel or common name in Thai, Plue), Schefflera leucantha R.Vig. (common name in Thai, Hanuman Prasan Kai), Andrographis paniculata (Burm.f.) Nees (common name in Thai, Fa Thalai Chon), Houttuynia cordata Thunb. (common name in Thai, Khao Thong), Psidium guajava L. (common name in Thai, Farang), Centella asiatica (common name in Thai, Bao Bog), Rhinacanthus nasutus(L.) Kurz. (common name in Thai, Thong Phan Chang), Thunbergia laurifolia Lindl. (common name in Thai, Rang Chuet), and Ocimim gratissimum Linn. (common name in Thai, Yee Ra). Plant samples were washed, cut, frozen in liquid nitrogen and ground to a fine powder, and solubilized in extraction buffer $(10 \mathrm{mM}$ sodium acetate buffer $\mathrm{pH} 5.2+0.5 \%$ polyvinylpolypyrrolidone (PVPP)) [10]. The cell lysates were centrifuged at 12,000 rpm, $4{ }^{\circ} \mathrm{C}, 20 \mathrm{~min}$. After centrifugation, the supernatant was collected. The crude protein supernatants were filtered sterile through $0.45 \mu \mathrm{m}$ membrane filters. The protein concentration was determined by the Bradford method [11].

\section{Antifungal activity testing of the extracts from Thai medicinal plants}

The antifungal assay using an agar well diffusion technique was performed $[12,13]$. The human pathogenic fungi used were Candida albicans ATCC90028, Cryptococcus neoformans ATCC90112, Aspergillus fumigatus NCPF7367, and T. marneffei ATCC200051. To prepare the fungi for antifungal assay, a yeast colony of $C$. albicans, and $C$. neoformans were inoculated into Sabouraud's dextrose broth (SDB) and incubated in a shaker at $35{ }^{\circ} \mathrm{C}$ for 24 and $48 \mathrm{~h}$, respectively. A yeast-like colony of $T$. marneffei was cultured in a brain heart infusion broth (BHIB) at $37^{\circ} \mathrm{C}$ for $96 \mathrm{~h}$. The number of yeast cells was enumerated using hemacytometer and the culture was adjusted to $10^{8}$ cells $/ \mathrm{mL}$. Mold colony of $A$. fumigatus, and T. marneffei was grown on Aspergillus nidulans minimal medium (ANM: $1 \%$ glucose with $\left.1 \mathrm{mM} \mathrm{NH}_{4}\left(\mathrm{SO}_{4}\right)_{2}\right)$ at $25{ }^{\circ} \mathrm{C}$ for 7 - 10 days. The conidia were collected by scraping from the colony surface, suspended in PBS-0.1\% tween, enumerated, and adjusted to a final concentration of $4-5 \times 10^{3}$ conidia/mL. The tested fungi were spread on the surface of Muller Hinton Agar (MHA) with $2 \%$ glucose and $0.5 \mu \mathrm{g} / \mathrm{mL}$ methylene blue for C. albicans ATCC90028 and C. neoformans, MHA with $2 \%$ glucose for $A$. fumigatus, and RPMI agar for T. marneffei (yeast and mold phase). Then, using a sterile borer (5 $\mathrm{mm}$, diameter), wells were created on the agar plates. After that, the well was filled with $200 \mu \mathrm{g}$ of plant protein extract. The plates were incubated at appropriate growth condition for each fungus as follows: $C$. 
albicans, $35^{\circ} \mathrm{C}$ for $24 \mathrm{~h}$; A. fumigatus and C. neoformans, $37^{\circ} \mathrm{C}$ for $48 \mathrm{~h}$; yeast phase of T. marneffei, 37 ${ }^{\circ} \mathrm{C}$ for $72 \mathrm{~h}$, and mold phase of T. marneffei, $25^{\circ} \mathrm{C}$ for $96 \mathrm{~h}$. The qualitative control included growth control (tested fungi only), a medium control (medium only), positive control (tested fungi with 10 $\mu \mathrm{g} / \mathrm{mL}$ Amphotericin B), and negative control (tested fungi with $\mathrm{CH}_{3} \mathrm{COONa}$ ). The antifungal effects recorded were reported as follows: -, no suppression; +, suppression, with detectable inhibition zones around the wells. The experiments were performed in triplicate.

\section{Protein precipitation and size fractionation}

Total proteins from the crude extracts of $R$. nasutus, and A. paniculata were precipitated. Precipitation was performed at an $80 \%$ saturation level of ammonium sulphate [14]. After precipitation, the protein was dialyzed in $10 \mathrm{mM}$ sodium acetate buffer at $4{ }^{\circ} \mathrm{C}$ with 4 times changing the buffer within $24 \mathrm{~h}(1,2,3$, and $18 \mathrm{~h})$. The precipitated protein from $R$. nasutus and A. paniculata were sequentially centrifuged in the column with molecular weight cut-off 30- and 10-kDa (GE Healthcare Life Sciences) to isolate the proteins into fractions of $>30 \mathrm{kDa}$ (fraction A), $10-30 \mathrm{kDa}$ (fraction $\mathrm{B}$ ) and $<10 \mathrm{kDa}$ (fraction $\mathrm{C}$ ). Each fraction was, then, used for antifungal activity testing.

\section{SDS PAGE method}

The fingerprinting profile for plant proteins pattern was determined by using the SDS-PAGE technique. Five micrograms of each protein sample were loaded into an $18 \%$ acrylamide gel or NuPAGE Novex 4 - $20 \%$ Bis-Tris $1.0 \mathrm{~mm}$ minigels (Invitrogen). A protein standard marker (GeneDirectX and Thermo Scientific ${ }^{\mathrm{TM}}$ ) was used in each run. The electrophoresis was performed for approximately $1-4 \mathrm{~h}$ using a constant voltage $(60-200 \mathrm{~V})$. The protein band was visualized by Coomassie Brilliant Blue (Thermo Scientific ${ }^{\mathrm{TM}}$ Imperial ${ }^{\mathrm{TM}}$ Protein) staining.

\section{Anti-T. marneffei activity of the partially purified fractions}

The partially purified fractions were diluted to a final concentration of $200 \mu \mathrm{g} / \mathrm{mL}$ using the standard broth microdilution techniques [15-17]. Briefly, $50 \mu \mathrm{l}$ of each fraction containing $400 \mu \mathrm{g} / \mathrm{mL}$ protein was placed into a sterile 96-well microtiter plate. An equal volume of T. marneffei suspensions in RPMI 1640 medium $\left(0.5-2.5 \times 10^{3}\right.$ cells $/ \mathrm{mL}$ for yeast, $0.4-5 \times 10^{4}$ conidia $/ \mathrm{mL}$ for mold $)$ was, then, added to each well, making the final concentration of protein in each fraction $200 \mu \mathrm{g} / \mathrm{mL}$. Plates were incubated at $37{ }^{\circ} \mathrm{C}$ for $72 \mathrm{~h}$ for yeast phase-T. marneffei and 96 days at $25{ }^{\circ} \mathrm{C}$ for mold phase-T. marneffei. Then, a resazurin indicator was added to each well [18]. The results were interpreted based on a color change from blue to pink in the presence of fungal growth. Blue or purple color of wells indicated growth inhibition or no growth. Amphotericin B and culture medium alone were used as the positive and negative control in each run. Three replicates were performed. The average inhibition concentrations were determined for each protein fraction.

\section{Determination of the minimal inhibitory concentration (MIC) and minimal fungicidal concentration (MFC)}

The MICs of the partial purified-fraction were determined by a broth microdilution method according to a modification of M27-A4 and M38-A3 protocols $[15,16]$. The tests were performed similarly to the previously mentioned screening tests of the partially purified fractions, except for the 2fold serial dilutions of crude extracts were prepared, ranging from $0.25-128 \mu \mathrm{g} / \mathrm{mL}$. After incubation under appropriate conditions, the lowest concentration of extract that inhibited growth, showing blue or purple color, was recorded as the MIC. If there is no inhibition at the maximum concentration tested (128 $\mu \mathrm{g} / \mathrm{mL}$ ), the $\mathrm{MIC}$ of $>128 \mu \mathrm{g} / \mathrm{mL}$ was, then, recorded.

The MFCs were determined by dropping a $10 \mu \mathrm{L}$ of the mixtures from the wells of MIC concentration and higher concentrations onto the surface of a brain heart infusion agar (BHA) for yeast, and Aspergillus minimal medium (ANM: $1 \%$ glucose $+1 \mathrm{mM} \mathrm{NH}_{4}\left(\mathrm{SO}_{4}\right)_{2}$ ) for mold. The colony-forming unit (CFU) was observed after incubation at either $37^{\circ} \mathrm{C}$ for $72 \mathrm{~h}$ (yeast form) and $25^{\circ} \mathrm{C}$ for $96 \mathrm{~h}$ (mold form). The lowest concentration showing no visible growth on the agar plate was recorded as the MFC 
http://wjst.wu.ac.th

value. The value of $>128 \mu \mathrm{g} / \mathrm{mL}$ was recorded if no CFU was observed at the maximum concentration tested.

\section{Results and discussion}

\section{The yield of protein extracts from Thai medicinal plants}

Ten Thai medicinal plants were chosen based on their traditional usage for the treatment of fungal infections or previous evidence supporting the antifungal properties [19]. The sufficient number of total proteins could be isolated from 7 plants i.e., S. alata, S. leucantha, A. paniculata, P. guajava, R. nasutus, T. laurifolia, and O. gratissimum, with the yields varied from 1.29 to $3.57 \mathrm{mg} / \mathrm{g}$ leaves (Table 1). The plant antifungal protein pattern is shown in the SDS-PAGE technique (Figure 1). The attempts to isolate proteins from the rest 3 plants $(P$. betle, $H$. cordata, and $C$. asiatica) were failed since they might contain a too low number of proteins in their leaves. Additionally, the yields depended on the isolation method which is affected by the manual grinding efficiency. The yields can be maximized by using more efficient methods, such as digestion of the cell wall before chemical lysis of the cells in the future.

Table 1 Plants crude protein supernatants contents.

\begin{tabular}{lc}
\hline \multicolumn{1}{c}{ Plants } & $\begin{array}{c}\text { Protein concentration in crude supernatant } \\
\text { (mg/g leaves) }\end{array}$ \\
\hline Senna alata (Chum-Het-Thet) & 3.07 \\
Schefflera leucantha (Hanuman Prasan Kai) & 3.57 \\
Andrographis paniculata (Fa Thalai Chon) & 3.39 \\
Psidium guajava (Farang) & 1.29 \\
Rhinacanthus nasutus (Thong Phan Chang) & 2.79 \\
Thunbergia laurifolia (Rang Chuet) & 1.88 \\
Ocimim gratissimum (Yee Ra) & 1.87 \\
Houttuynia cordata (Khao Thong) & $\mathrm{ND}$ \\
Centella asiatica (Bao Bog) & $\mathrm{ND}$ \\
Piper betle (Plue) & $\mathrm{ND}$ \\
\hline
\end{tabular}

Note: ND: not detectable 
http://wjst.wu.ac.th

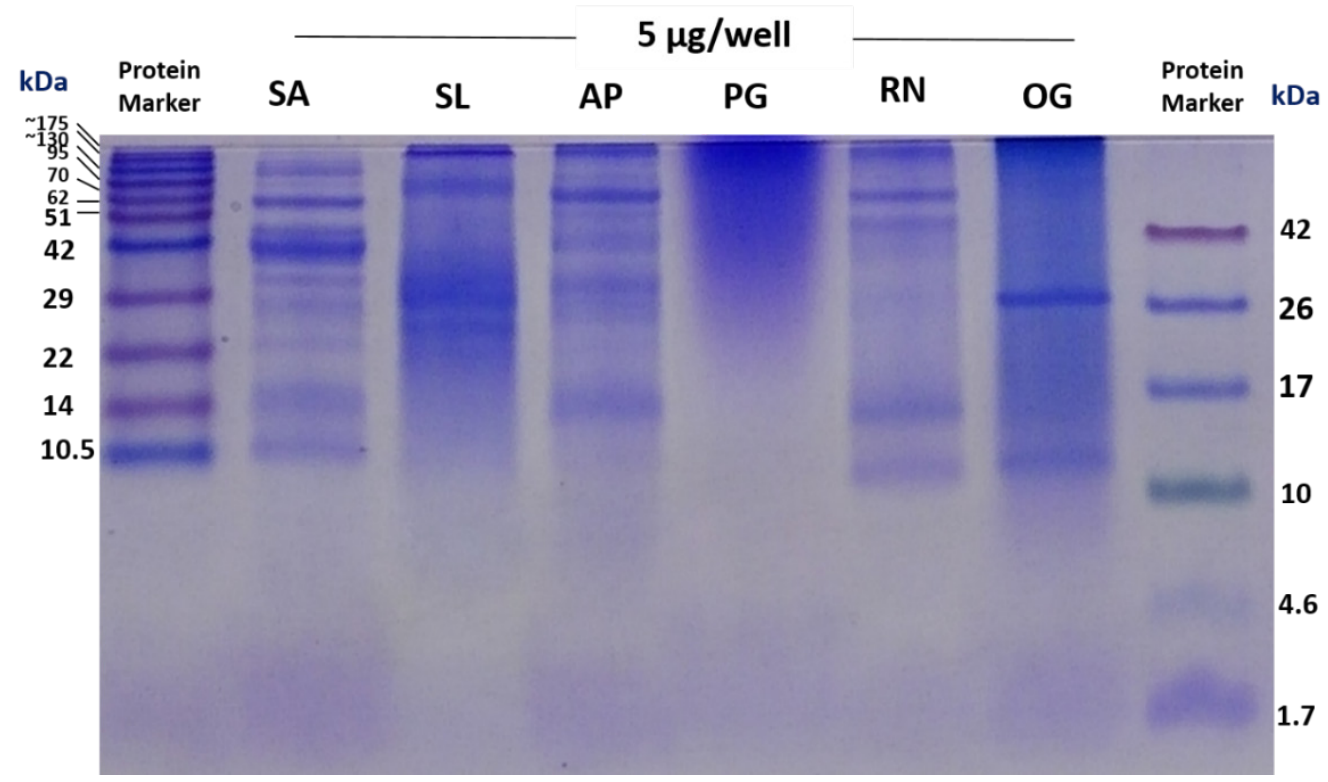

Figure 1 Detection of plant antifungal protein patterns using SDS-PAGE. Fingerprinting profile for plant protein pattern by using SDS-PAGE (18\% acrylamide gel). Protein bands were visualized by Coomassie Brilliant Blue staining. Lane 1: Standard protein maker (GeneDirectX), Lane 2: SA = Senna alata (L.) Roxb. (Chum Het Thet), Lane 3: SL= Schefflera leucantha (Hanuman Prasan Kai), Lane 4: AP = Andrographis paniculata (Burm.f.) Nees (Fa Thalai Chon), Lane 5: PG = Psidium guajava L. (Farang), Lane 6: RN = Rhinacanthus nasutus (L.) Kurz. (Thong Phan Chang), Lane 7: OG = Ocimim gratissimum Linn. (Yee Ra), Lane 8: low range protein marker (Thermo Scientific ${ }^{\mathrm{TM}}$ )

Screening assay for selection of Thai medicinal plants containing antifungal activity to opportunistic fungal pathogens

Total crude proteins from 7 Thai medicinal plants were tested for antifungal activity against $C$. albicans (CA), C. neoformans (CN), T. marneffei-yeast (TMY), T. marneffei-mold (TMM) and $A$. fumigatus (AF) using the agar diffusion method. In order to determine whether the antifungal activity presented in the whole extracts came from antifungal protein, the precipitated proteins were used. The inhibition zone in millimeters was recorded and showed in Table 2 and Figure 2.

In most cases, the antifungal activity in precipitated proteins was greater than those from crude extracts. While the whole extracts from some plants could not inhibit the growth of the tested fungi, their precipitated proteins inhibited the growth. This result suggested the presence of antifungal peptides but the concentration was low in the whole extract and/or showing the action of types of antifungal other than proteins. For example, the precipitated proteins of $S$. alata, O. gratissimum and S. leucantha, A. paniculata and $R$. nasutus, and $R$. nasutus inhibited growth of the yeast phase-T. marneffei, mold phase- $T$. marneffei, and $C$. neoformans, respectively; but the whole extract did not show the inhibition zone. Similarly, the antifungal activity of precipitated proteins was greater than those from crude extracts [20]. The greater activity might due to the result of purification and a higher concentration of bioactive proteins [20].

The extracts from $P$. guajava, A. paniculata and $R$. nasutus showed antifungal activity in both whole extracts and precipitated proteins, suggesting the presence of antifungal peptides. From the result, the $P$. guajava extracts displayed antifungal activity against yeasts $C$. albicans and $C$. neoformans. The extracts from $S$. alata, O. gratissimum, $S$. leucantha, $A$. paniculata and $R$. nasutus showed antifungal activity to T. marneffei (yeast phase). The extracts from $A$. paniculata and $R$. nasutus also showed an 
http://wjst.wu.ac.th

antifungal activity to the mold phase of T. marneffei. However, only A. fumigatus growth was inhibited by $R$. nasutus. Among all the extracts, $R$. nasutus has the broadest antifungal activity.

Interestingly, almost all extracts contain antifungal activity to the pathogenic yeast phase of $T$. marneffei but not to the mold phase. This is the first report for the different reactivity of natural extracts on the different phases of this dimorphic pathogenic fungus. The underlying mechanisms are unknown, but they might be forming the difference in fungal cell wall and/or cell membrane composition and arrangement between 2 living phases. From the literature review, the antifungal activity of antifungal peptides was initially attributed to either fungal cell lysis or interference with fungal cell wall synthesis [21].

In conclusion, the most effective antifungal activities were found in the extracts from A. paniculata, $R$. nasutus and P. guajava. They showed the highest activity against T. marneffei (yeast phase), followed by C. neoformans, C. albicans, T. marneffei (mold phase) and A. fumigatus (Table 2).

Table 2 Preliminary antifungal activity of crude protein supernatants and precipitated proteins on opportunistic fungal pathogens

\begin{tabular}{|c|c|c|c|c|c|c|}
\hline \multirow[t]{2}{*}{ Plants } & \multirow[t]{2}{*}{ Protein } & \multicolumn{5}{|c|}{$\begin{array}{c}\text { Antifungal activity } \\
(\text { Mean } \pm \text { SD of inhibition zone diameter }(\mathrm{mm}))\end{array}$} \\
\hline & & $\mathbf{C A}$ & $\mathbf{C N}$ & TMY & TMM & $\mathbf{A F}$ \\
\hline \multirow{2}{*}{ Senna alata } & $\begin{array}{c}\text { Crude } \\
\text { supernatant }\end{array}$ & - & - & - & - & - \\
\hline & $\begin{array}{l}\text { Precipitated } \\
\text { protein }\end{array}$ & - & - & $\stackrel{+}{+}$ & - & - \\
\hline \multirow{2}{*}{ Schefflera leucantha } & $\begin{array}{c}\text { Crude } \\
\text { supernatant }\end{array}$ & - & - & - & - & - \\
\hline & $\begin{array}{l}\text { Precipitated } \\
\text { protein }\end{array}$ & - & - & $\begin{array}{c}+ \\
+ \\
(30.50 \pm 0.41)\end{array}$ & - & - \\
\hline \multirow{2}{*}{$\begin{array}{l}\text { Andrographis } \\
\text { paniculata }\end{array}$} & $\begin{array}{c}\text { Crude } \\
\text { supernatant }\end{array}$ & - & - & $\stackrel{+}{+}(23.33 \pm 2.49)$ & - & - \\
\hline & $\begin{array}{l}\text { Precipitated } \\
\text { protein }\end{array}$ & - & - & $\stackrel{+}{+}(30.00 \pm 0.00)$ & 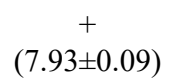 & - \\
\hline \multirow{2}{*}{ Psidium guajava } & $\begin{array}{c}\text { Crude } \\
\text { supernatant }\end{array}$ & $\stackrel{+}{\stackrel{+}{(10.83} \pm 0.24)}$ & $\stackrel{+}{+}$ & - & - & - \\
\hline & $\begin{array}{l}\text { Precipitated } \\
\text { protein }\end{array}$ & $\stackrel{+}{+}$ & $\stackrel{+}{+}$ & - & - & - \\
\hline \multirow{2}{*}{ Rhinacanthus nasutus } & $\begin{array}{l}\text { Crude } \\
\text { supernatant }\end{array}$ & - & - & $\begin{array}{c}+ \\
+ \\
(38.50 \pm 1.08)\end{array}$ & - & $\begin{array}{c}+ \\
(23.00 \pm 0.82)\end{array}$ \\
\hline & $\begin{array}{l}\text { Precipitated } \\
\text { protein }\end{array}$ & - & $\begin{array}{c}+ \\
(7.80 \pm 0.16)\end{array}$ & $\stackrel{+}{+}(25.00 \pm 0.00)$ & 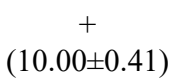 & $\stackrel{+}{+}$ \\
\hline \multirow{2}{*}{ Thunbergia laurifolia } & $\begin{array}{c}\text { Crude } \\
\text { supernatant }\end{array}$ & - & - & - & - & - \\
\hline & $\begin{array}{l}\text { Precipitated } \\
\text { protein }\end{array}$ & - & - & - & - & - \\
\hline \multirow{2}{*}{ Ocimim gratissimum } & $\begin{array}{c}\text { Crude } \\
\text { supernatant }\end{array}$ & - & - & - & - & - \\
\hline & $\begin{array}{l}\text { Precipitated } \\
\text { protein }\end{array}$ & - & - & $\begin{array}{c}+ \\
(28.53 \pm 0.41)\end{array}$ & - & - \\
\hline \multirow{2}{*}{\multicolumn{2}{|c|}{$\begin{array}{l}\text { Negative control: } 10 \mathrm{mM} \mathrm{CH}_{3} \mathrm{COONa} \\
\text { Positive control: AmphotericinB ( } 10 \\
\mu \mathrm{g} / \mathrm{mL})\end{array}$}} & - & - & - & - & - \\
\hline & & $\begin{array}{c}+ \\
(21.67 \pm 0.47)\end{array}$ & $\begin{array}{c}+ \\
(25.83 \pm 0.24)\end{array}$ & $\begin{array}{c}+ \\
(26.60 \pm 0.43)\end{array}$ & $\begin{array}{c}+ \\
(10.17 \pm 0.21)\end{array}$ & $\begin{array}{c}+ \\
(10.00 \pm 0.00)\end{array}$ \\
\hline
\end{tabular}

Notes: +: suppression, -: no suppression, CA: Candida albicans ATCC90028, CN: Cryptococcus neoformans

ATCC90112, TMY: Talaromyces marneffei (yeast phase) ATCC200051, TMM: Talaromyces marneffei (mold phase)

ATCC200051, AF: Aspergillus fumigatus NCPF7367. Value are means $(\mathrm{n}=3) \pm \mathrm{SE}$ 


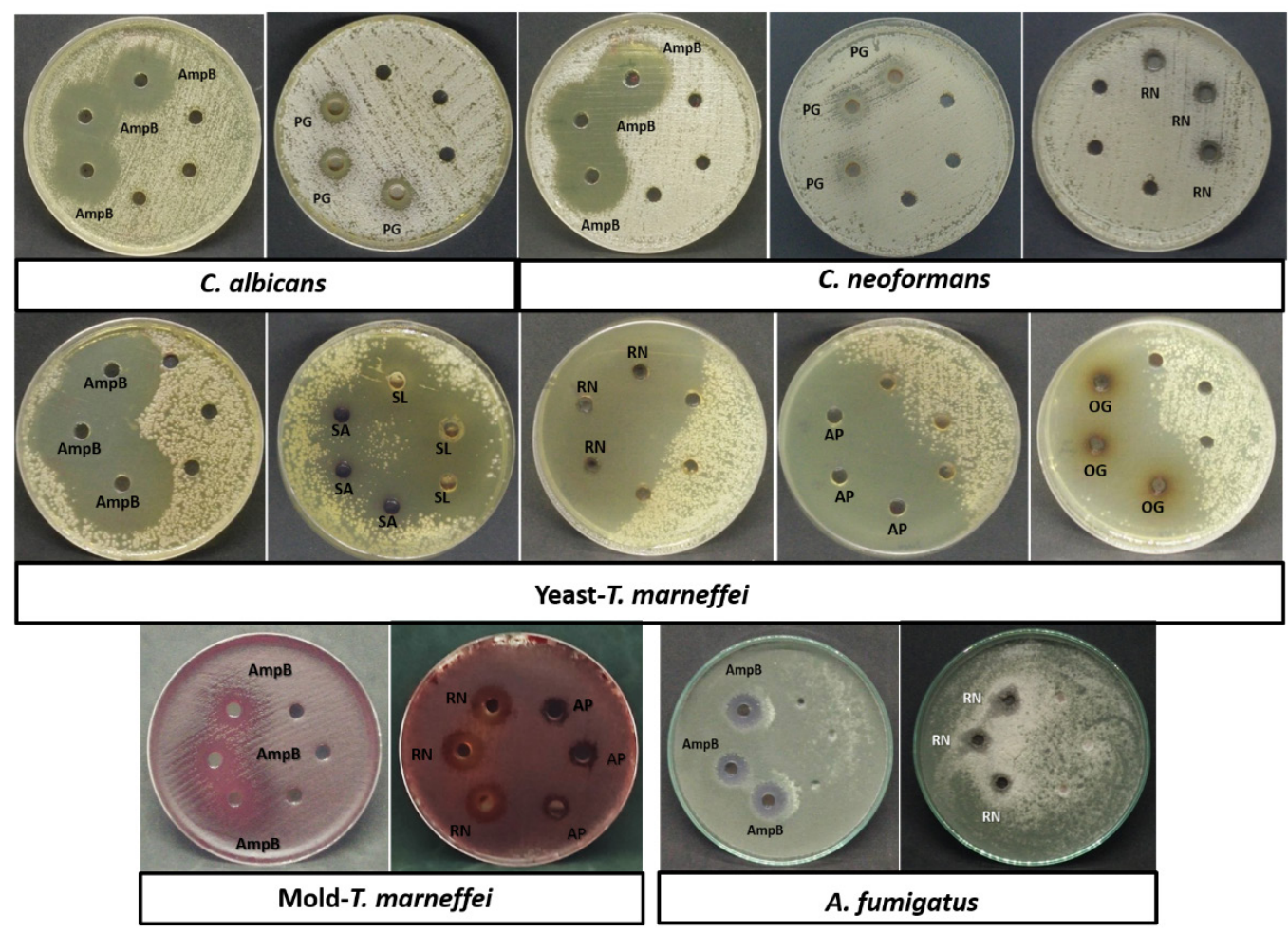

Figure 2 Antifungal activities of precipitated protein were evaluated by agar well diffusion method against the human pathogen fungi. The tested fungi (as indicated) were spread onto the surface of the agar medium and the precipitated protein from Thai medical plants was filled in the wells. The plants used were SA = Senna alata (L.) Roxb. (Chum Het Thet), SL = Schefflera leucantha (Hanuman Prasan Kai), $\mathrm{AP}=$ Andrographis paniculata (Burm.f.) Nees (Fa Thalai Chon), PG = Psidium guajava L. (Farang), RN = Rhinacanthus nasutus (L.) Kurz. (Thong Phan Chang), OG = Ocimim gratissimum Linn. (Yee Ra). The inhibition zones were recorded. The assays were performed in triplicate.

\section{Anti-T. marneffei activity of the partially purified protein fractions}

To initially determine the size of anti-T.marneffei antifungal peptides, the extracts from $R$. nasutus and $A$. paniculata that showed the most inhibition reactivities to $T$. marneffei were chosen for size fractionation. The extracts were sequentially centrifuged in the 30 and $10 \mathrm{kDa}$ - cut-off centrifugal tubes and fractionated into $>30$ (fraction A), $10-30$ (fraction B) and $<10 \mathrm{kDa}$ (fraction $\mathrm{C}$ ). All of the protein fractions showed inhibitory activity at the concentration of $200 \mu \mathrm{g} / \mathrm{mL}$. The MIC and MFC values were investigated and the result is shown in Table 3. The MIC values varied from 2 to $128 \mu \mathrm{g} / \mathrm{mL}$. The MIC and MFC of all fractions to T. marneffei yeast phase ranged from 2 to $>128 \mu \mathrm{g} / \mathrm{mL}$ and 16 to $>128$ $\mu \mathrm{g} / \mathrm{mL}$, respectively. The most effective fraction was the $>30 \mathrm{kDa}$ from $R$. nasutus, containing the MIC of $2 \mu \mathrm{g} / \mathrm{mL}$ and MFC of $16 \mu \mathrm{g} / \mathrm{mL}$ fungicidal activity. Even not as effective as the Amphotericin B (MIC $0.5 \mu \mathrm{g} / \mathrm{mL}$ ) but it can be an option in the case of low toxicity. The other tested fractions also contain the antifungal activities with different MICs and MFCs values, suggesting the different types of antifungal peptides present in the fractions. Therefore, it is worth purifying antifungal peptides and characterize molecular mechanisms for anti-T. marneffei in each plant.

Interestingly, our study showed the different effects of AFPs to the different phases of T. marneffei, which the underlying antifungal mechanism is currently unknown. A previous study found that the MIC of conventional antifungal drugs was difference for the mold and yeast form of this fungus [22]. The 
http://wjst.wu.ac.th

MICs of amphotericin B, itraconazole, and ketoconazole to the mycelial form were higher than those recorded for the yeast [21]. Moreover, T. marneffei's yeast form is more sensitive to fluconazole and itraconazole while the mycelial form displayed greater susceptibility to amphotericin B and 5-FC [23]. Furthermore, the susceptibilities of 57 T. marneffei strains to various antifungal drugs and showed that posaconazole was more active in the yeast phase while anidulafungin showed higher activity to the mold phase more than the yeast phase [17]. Altogether, the data implicated that the drugs affecting ergosterol and $\beta$-glucans, the contents that amounts differ in mold and yeast phases, had a different effect on this dimorphic fungus. According to our data, the antifungal peptides from Thai medicinal plants showed the most effective inhibition of the yeast pathogenic form. Thus, they should have advantages in the treatment of T. marneffei infection and their mechanism should be further determined.

Table 3 The minimal inhibitory concentration (MIC) and minimal fungicidal concentration (MFC) of partially purified fractions on Talaromyces marneffei ATCC200051.

\begin{tabular}{|c|c|c|c|c|c|c|}
\hline \multirow{2}{*}{$\begin{array}{l}\text { Partially purified } \\
\text { fractions }\end{array}$} & \multicolumn{3}{|c|}{ Yeast phase } & \multicolumn{3}{|c|}{ Mold phase } \\
\hline & $\begin{array}{c}\text { Screening } \\
(200 \mu \mathrm{g} / \mathrm{mL})\end{array}$ & $\begin{array}{c}\text { MIC } \\
(0.25-128 \\
\mu \mathrm{g} / \mathrm{mL})\end{array}$ & $\begin{array}{c}\text { MFC } \\
(0.25-128 \\
\mu \mathrm{g} / \mathrm{mL})\end{array}$ & $\begin{array}{c}\text { Screening } \\
(200 \\
\mu \mathrm{g} / \mathrm{mL})\end{array}$ & $\begin{array}{c}\text { MIC } \\
(0.25-128 \\
\mu \mathrm{g} / \mathrm{mL})\end{array}$ & $\begin{array}{c}\text { MFC } \\
(0.25-128 \\
\mu \mathrm{g} / \mathrm{mL})\end{array}$ \\
\hline AP-A $(>30 \mathrm{kDa})$ & + & 64 & $>128$ & + & $>128$ & $>128$ \\
\hline AP-B (10 - 30 kDa) & + & 128 & 128 & + & $>128$ & $>128$ \\
\hline AP-C $(<10 \mathrm{kDa})$ & + & 64 & 128 & + & 128 & $>128$ \\
\hline $\mathrm{RN}-\mathrm{A}(>30 \mathrm{kDa})$ & + & 2 & 16 & + & 128 & $>128$ \\
\hline RN-B (10 - $30 \mathrm{kDa})$ & + & 64 & 128 & + & 128 & $>128$ \\
\hline $\mathrm{RN}-\mathrm{C}(<10 \mathrm{kDa})$ & + & 128 & 128 & + & 128 & $>128$ \\
\hline AmphotericinB & + & 0.5 & 4 & + & 2 & 8 \\
\hline
\end{tabular}

Notes: RN: Rhinacanthus nasutus, AP: Andrographis paniculata, +: positive result (growth of Talaromyces marneffei was inhibited).

\section{Conclusions}

Antifungal peptides/proteins were presented in the diverse groups of Thai medicinal plants. The crude protein and precipitated protein from R. nasutus, A. paniculata, P. guajava, S. alata, S. Leucantha, and $O$. gratissimum inhibited at least one of the tested opportunistic fungi. The extracts were most active against T. marneffei (yeast phase) followed by C. neoformans, C. albicans, T. marneffei (mold phase), and A.fumigatus, respectively. In T.marneffei, partial purified form R. nasutus, and A. paniculata showed strong to moderate inhibitory activity to the yeast phase while showing only weak inhibition to the mold phase. So, A. paniculata and $R$. nasutus extracts can be further subjected to study for therapeutic purposes. 


\section{Acknowledgements}

This work is financial supported from the Teaching Assistant and Research Assistant Scholarships Graduate School, Chiang Mai University, the Research Fund, Faculty of Medicine, Chiang Mai University (092/2562), National Research Council of Thailand (NRCT): GSCMU(NRCT)/09/2562 and the Faculty of Medicine Graduate Student Scholarship, Chiang Mai University, Thailand. We acknowledge the Herb for Health Unit, Faculty of Pharmacy, Chiang Mai University, Thailand for providing plants materials.

\section{References}

[1] GD Brown, DW Denning and SM Levitz. Tackling human fungal infections. Science 2012; 336, 647.

[2] K Lohner and R Leber. Antifungal host defense peptides. In: RM Epand (Ed.). Host defense peptides and their potential as therapeutic agents. Springer International Publishing, Switzerland, 2016, p. $27-55$.

[3] NM Revie, KR Iyer, N Robbins and LE Cowen. Antifungal drug resistance: Evolution, mechanisms and impact. Curr. Opin. Microbiol. 2018; 45, 70-6.

[4] A Butts and DJ Krysan. Antifungal drug discovery: Something old and something new. PLoS Pathog. 2012; 8, e1002870.

[5] N Hegedüs and F Marx. Antifungal proteins: More than antimicrobials? Fungal Biol. Rev. 2013; 26, $132-45$.

[6] DA Dias, S Urban and U Roessner. A historical overview of natural products in drug discovery. Metabolites 2012; 2, 303-36.

[7] A Matejuk, Q Leng, MD Begum, MC Woodle, P Scaria, ST Chou and AJ Mixson. Peptide-based antifungal therapies against emerging infections. Drugs Future 2010; 35, 197.

[8] H Szappanos, GP Szigeti, B Pal, Z Rusznak, G Szucs, E Rajnavolgyi, J Balla, G Balla, E Nagy, E Leiter, I Pócsi, S Hagen, V Meyer and L Csernoch. The antifungal protein AFP secreted by Aspergillus giganteus does not cause detrimental effects on certain mammalian cells. Peptides 2006; 27, 1717-25.

[9] S Hagen, F Marx, AF Ram and V Meyer. The antifungal protein AFP from Aspergillus giganteus inhibits chitin synthesis in sensitive fungi. Appl. Environ. Microbiol. 2007; 73, 2128-34.

[10] M Thapliyal, A Bisht and A Singh. Isolation of antibacterial protein/peptide from Ficus glomerata leaf. Int. J. Curr. Pharm. Res. 2016; 8, 24-7.

[11] MM Bradford. A rapid and sensitive method for the quantitation of microgram quantities of protein utilizing the principle of protein-dye binding. Anal. Biochem. 1976; 72, 248-54.

[12] CLSI. Method for antifungal disk diffusion susceptibility testing of yeasts. In: PA Wayne (Ed.). CLSI guideline M44. $3^{\text {rd }}$ ed. Clinical and Laboratory Standards Institute, Pennsylvania, 2018.

[13] CLSI. Method for antifungal disk diffusion susceptibility testing of nondermatophyte filamentous fungi. In: PA Wayne (Ed.). Approved Guideline. CLSI Document M51. Clinical and Laboratory Standards Institute, Pennsylvania, 2010.

[14] QK Huynh, JR Borgmeyer, CE Smith, LD Bell and DM Shah. Isolation and characterization of a 30 $\mathrm{kDa}$ protein with antifungal activity from leaves of Engelmannia pinnatifida. Biochem. J. 1996; 316, 723-7.

[15] CLSI. Reference method for broth dilution antifungal susceptibility testing of yeasts. In: PA Wayne (Ed.). CLSI document M27. $4^{\text {th }}$ ed. Clinical and Laboratory Standards Institute, Pennsylvania, 2017.

[16] CLSI. Reference method for broth dilution antifungal susceptibility testing of filamentous fungi. In: PA Wayne (Ed.). CLSI document M38. $3^{\text {rd }}$ ed. Clinical and Laboratory Standards Institute, Pennsylvania, 2017.

[17] SK Lau, GC Lo, CS Lam, WN Chow, AH Ngan, AK Wu, DN Tsang, CW Tse, TL Que, Tang BS and PC Woo. In vitro activity of Posaconazole against Talaromyces marneffei by broth microdilution and Etest methods and comparison to Itraconazole, Voriconazole, and Anidulafungin. Antimicrob. Agents Chemother. 2017; 61, e01480. 
http://wjst.wu.ac.th

[18] SD Sarker, L Nahar and Y Kumarasamy. Microtitre plate-based antibacterial assay incorporating resazurin as an indicator of cell growth, and its application in the in vitro antibacterial screening of phytochemicals. Methods 2007; 42, 321-4.

[19] PHARM database, Available at: http://www.medplant.mahidol.ac.th/index.asp, accessed May 2018.

[20] A Jamil, M Shahid, MMUH Khan and M Ashraf. Screening of some medicinal plants for isolation of antifungal proteins and peptides. Pak. J. Bot. 2007; 39, 211-21.

[21] CP Selitrennikoff. Antifungal proteins. Appl. Environ. Microbiol. 2001; 67, 2883-94.

[22] B Sar, S Boy, C Keo, CC Ngeth, N Prak, M Vann, M Didier and JL Sarthou. In vitro antifungal-drug susceptibilities of mycelial and yeast forms of Penicillium marneffei isolates in Cambodia. J. Clin. Microbiol. 2006; 44, 4208-10.

[23] AS Sekhon, AK Garg, AA Padhye and Z Hamir. In vitro susceptibility of mycelial and yeast forms of Penicillium marneffei to amphotericin B, fluconazole, 5-fluorocytosine and itraconazole. Eur. J. Epidemiol. 1993; 9, 553-8. 